\title{
SARCINA VENTRICULI IN HUMAN FAECES
}

\author{
J. S. CROWTHER \\ Bacteriology Department, Wright-Fleming Institute, \\ St Mary's Hospital Medical School, London, W.2
}

SARCINA VENTRICULI was first observed by Goodsir (1842) in the stomach contents of a patient with gastric fermentation. The organism was subsequently reported in similar cases, but it was not isolated in pure culture from the human stomach until 1911, when Beijerinck showed that $S$. ventriculi could be grown only by using strictly anaerobic techniques; he had previously shown that the same organism occurred widely in the soil (Beijerinck, 1905).

Although $S$. ventriculi has been found frequently in the gastric contents and faeces of patients with gastro-intestinal disorders (Smit, 1933), it has never been reported as present in the faeces of healthy human adults. However, during a survey in which faeces from healthy adults in Britain, the United States, Uganda and South India were examined (Aries et al., 1969), S. ventriculi has been found in the faeces of some persons.

This paper describes the techniques used to isolate sarcinae and reports the distribution of the organism in human faeces.

\section{MATERIALS AND METHODS}

Source of faeces. Specimens of freshly voided faeces were collected from 106 people living on principally vegetarian diets and from 123 people living on mixed diets containing animal and vegetable foods. Each group contained men and women and all except one 8-yr-old Sudanese girl were adults.

Transport of faeces. Specimens of freshly voided faeces were transported to the WrightFleming Institute frozen in glycerol broth (Drasar, Shiner and McLeod, 1969) from all sources except the London vegetarians in which case the faeces were sent by post and frozen in glycerol broth immediately on arrival.

Isolation of sarcinae. Sarcina ventriculi is difficult to maintain alive in pure culture. However, it is known to form heat-resistant spores (Knöll, 1965; Canale-Parola, 1970) and on primary isolation from soil and mud it is relatively resistant to acid and to heat at $60^{\circ} \mathrm{C}$ (Smit); these properties provided the basis for selective isolation methods.

The faecal suspensions were thawed, serially diluted in Brain Heart Infusion (Oxoid) and heated for $10 \mathrm{~min}$. in a waterbath at $70^{\circ} \mathrm{C} ; 0.1 \mathrm{ml}$ of each dilution was spread on freshly poured meat infusion agar containing lactose, neutral red and egg-yolk (Willis and Hobbs' medium without neomycin), as described by Willis and Hobbs (1958), and incubated overnight at $37^{\circ} \mathrm{C}$ in an atmosphere of 90 per cent. hydrogen and 10 per cent. carbon dioxide. Stainless steel milking-machine pails with vacuum-tight lids (Fullwood Bland and Co.) fitted with vacuum taps and cold catalysts (" D " catalyst, Engelhard Industries) as described by Schaedler, Dubos and Costello (1965) were used in place of conventional anaerobic jars. The heating destroyed all non-sporing organisms. Colonies of sarcinae could readily be distinguished from those of clostridia and aerobic spore-bearing bacilli. Sarcinae formed 
pale yellow colonies $2-4 \mathrm{~mm}$ in diameter, and were usually surrounded by a yellow halo in the medium. Colonies were examined microscopically and subcultured aerobically and anaerobically.

Sarcinae were also isolated by plating either unheated or heated dilutions on freshly poured Tomato Juice Agar (Oxoid) adjusted to $p \mathrm{H} \mathrm{7.0} \mathrm{and} \mathrm{incubated} \mathrm{anaerobically} \mathrm{(Crecelius}$ and Rettger, 1943).

Malt extract enrichment cultures designed to isolate $S$. ventriculi from the soil (CanaleParola and Wolfe, 1960) were adjusted to several $p \mathrm{H}$ values over the range $2 \cdot 3-6 \cdot 0$, inoculated with faeces and incubated anaerobically. Cultures were examined daily for sarcinae by plating on Willis and Hobbs' medium and incubating anaerobically.

Maintenance of strains for biochemical tests. Cultures of sarcinae isolated from faeces were maintained at $+3^{\circ} \mathrm{C}$ in Robertson's cooked meat broth (Southern Group Laboratories) to which 1 per cent. of glucose had been added before they were autoclaved at $115^{\circ} \mathrm{C}$ for $20 \mathrm{~min}$. The medium did not require deoxygenation before inoculation. Cultures were grown overnight at $37^{\circ} \mathrm{C}$ and stored at $+3^{\circ} \mathrm{C}$. With this technique, strains have remained viable for $6 \mathrm{mth}$ without subculture.

A culture of $S$. ventriculi (HU1) originally isolated from soil (Stephenson and Dawes, 1970) was obtained from Professor E. A. Dawes, Department of Biochemistry, University of Hull, and maintained as described above.

\section{Biochemical tests}

Detection of cellulose. Two methods were used to detect cellulose in overnight cultures in basal medium containing 2 per cent. glucose. The bacterial cells were boiled in 1 per cent. sodium hydroxide, washed with water and suspended in Schultze's stain for cellulose (CanaleParola, Borasky and Wolfe, 1961). The cellulose stained reddish-purple. Cells from each overnight culture were suspended in buffer at $p \mathrm{H} \mathrm{4.0}$ containing cellulase (British Drug Houses) and incubated overnight at $37^{\circ} \mathrm{C}$. The cultures were examined microscopically for disruption of the double tetrad packets into smaller clusters and single cells. Suspensions without cellulase were used as controls.

Fermentation tests. The fermentation tests were modifications of those described by Cato et al. (1969).

$2.0 \mathrm{~g}$ of the test carbohydrate was added to a $100-\mathrm{ml}$ volume of basal medium containing: $2.0 \mathrm{~g}$ peptone, $1.0 \mathrm{~g}$ yeast extract, $0.05 \mathrm{~g}$ cysteine hydrochloride, $0.001 \mathrm{~g} \mathrm{CaCl}_{2}, 0.001 \mathrm{~g}$ $\mathrm{MgSO}_{4}, 0.005 \mathrm{~g} \mathrm{~K}_{2} \mathrm{HPO}_{4}, 0.005 \mathrm{~g} \mathrm{KH}_{2} \mathrm{PO}_{4}, 0.05 \mathrm{~g} \mathrm{NaHCO}_{3}$ and $0.01 \mathrm{~g} \mathrm{NaCl}$. The media were adjusted to $p \mathrm{H} 7 \cdot 1 \pm 0 \cdot 1$ with $8 \mathrm{~N}-\mathrm{NaOH}$ or $5 \mathrm{~N}-\mathrm{HCl}$ and autoclaved at $115^{\circ} \mathrm{C}$ for $20 \mathrm{~min}$. They did not require deoxygenation before inoculation. Two drops of an overnight culture in Robertson's cooked meat broth containing 1 per cent. glucose were used as the inoculum. All test cultures were incubated anaerobically.

Gas-liquid chromatography. Volatile products of glucose metabolism (ethanol and acetic and butyric acids) were detected by modifications of the methods described by Cato et al.

$4 \mathrm{ml}$ of an overnight culture in basal medium containing 2.0 per cent. glucose were acidified with $0.5 \mathrm{ml} 50$ per cent. aqueous sulphuric acid and extracted with $4 \mathrm{ml}$ diethyl ether. The mixture was centrifuged to break the emulsion and the ether layer was pipetted off and dried over magnesium sulphate. 1.0 $\mu \mathrm{l}$ was injected on to a column containing 10 per cent. polyethylene glycol on phosphoric acid-treated diatomite contained in a " 104 " Series chromatograph (Pye Instruments Ltd, Cambridge). A flame-ionisation detector was used. Reference solutions of ethanol and volatile fatty acids were prepared as described by Cato et al.

Nitrate reduction. $2 \cdot 0$ per cent. glucose was added to Nitrate Broth (Difco) and autoclaved at $115^{\circ} \mathrm{C}$ for $20 \mathrm{~min}$. Cultures were incubated anaerobically at $37^{\circ} \mathrm{C}$. Nitrate and nitrite were detected by conventional procedures (Cowan and Steel, 1965).

Gelatin liquefaction. Charcoal gelatin disks (Oxoid) were added to Robertson's cooked meat broth containing 1 per cent. glucose; the test organism was inoculated and the culture 
was incubated at $37^{\circ} \mathrm{C}$ for 14 days. Liquefaction was indicated by the appearance of free charcoal particles in the medium.

\section{RESULTS}

Sarcinae were readily isolated on either tomato juice agar or Willis and Hobbs' medium from faeces of people living on vegetarian diets. Tomato juice agar was the more selective for unheated specimens, but the heating of

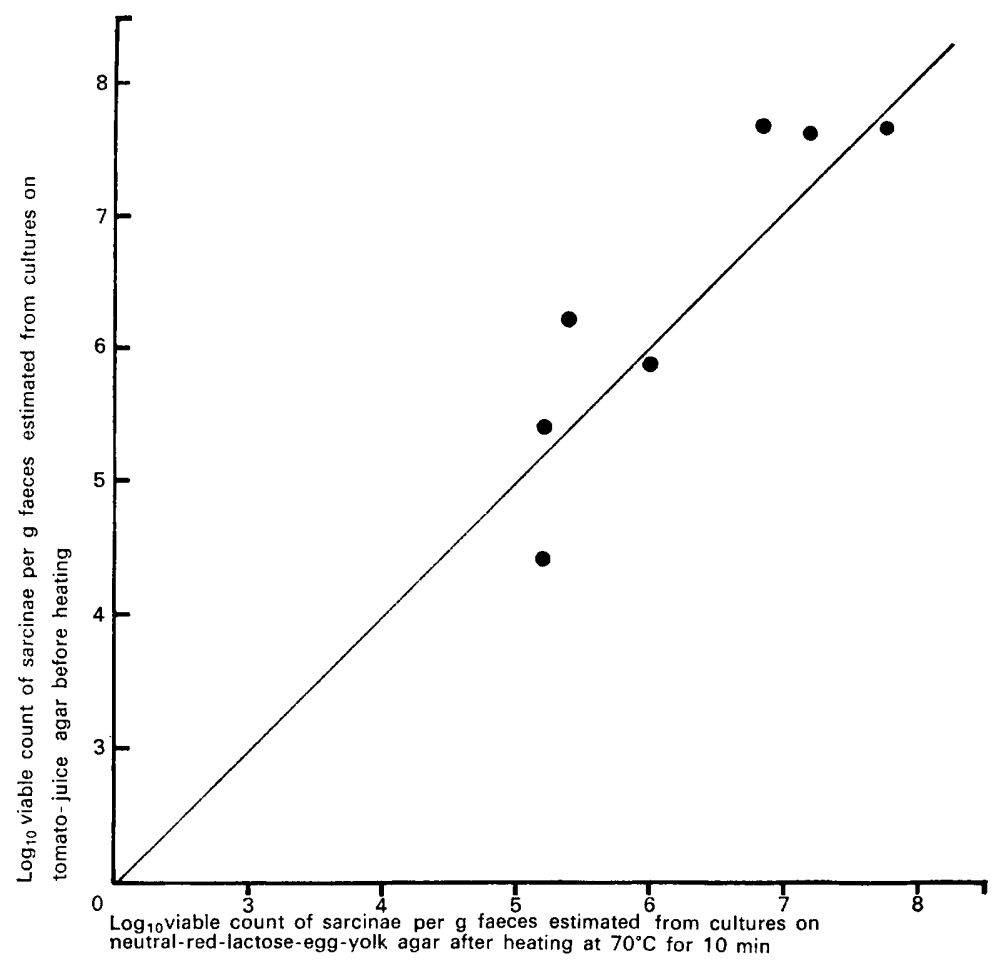

FIG. 1.-Comparison of methods of enumeration of viable Sarcina ventriculi in seven specimens of human faeces.

suspensions before they were plated on Willis and Hobbs' medium avoided overgrowth of the sarcinae by non-sporing organisms without consistently decreasing the viable counts of sarcinae (fig. 1).

It was not found possible to increase the yield of sarcinae from faeces by the use of the acid enrichment media described by Canale-Parola and Wolfe for the isolation of $S$. ventriculi from soil. Although cultivation at $p \mathrm{H} 4.0$ was highly selective, many strains of sarcinae were inhibited. At higher $p \mathrm{H}$ values the sarcinae were often outgrown by other organisms.

\section{Distribution of sarcinae in human faeces}

The simple heating method with subculture on Willis and Hobbs' medium was used to count sarcinae in faeces from healthy adults living on different 
TABLE I

The occurrence of anaerobic sarcinae in faeces from healthy adults on vegetarian and on mixed diets

\begin{tabular}{|c|c|c|c|}
\hline \multirow{2}{*}{ Population sampled } & \multirow{2}{*}{$\begin{array}{l}\text { Diet of } \\
\text { population } \\
\text { sampled }\end{array}$} & \multicolumn{2}{|c|}{ Number of specimens } \\
\hline & & cultivated & $\begin{array}{l}\text { found to contain } \\
\text { viable sarcinae }\end{array}$ \\
\hline $\begin{array}{l}\text { Ugandans living in and around Kampala } \\
\text { Indians living in and around Vellore } \\
\text { Strict vegetarians living in London }\end{array}$ & $\begin{array}{l}\text { Vegetarian } \\
\text { Vegetarian } \\
\text { Strict } \\
\quad \text { vegetarian }\end{array}$ & $\begin{array}{l}37 \\
51 \\
18\end{array}$ & $\begin{array}{r}31 \\
38 \\
6\end{array}$ \\
\hline $\begin{array}{l}\text { London students and laboratory staff } \\
\text { Edinburgh students and laboratory staff } \\
\text { English immigrants in Kampala } \\
\text { Caucasian laboratory staff in Atlanta } \\
\text { Hospital staff in Khartoum }\end{array}$ & Mixed & $\begin{array}{l}55 \\
23 \\
16 \\
16 \\
13\end{array}$ & $\begin{array}{l}0 \\
0 \\
0 \\
1 \\
1^{*}\end{array}$ \\
\hline
\end{tabular}

* Eight-year-old girl.
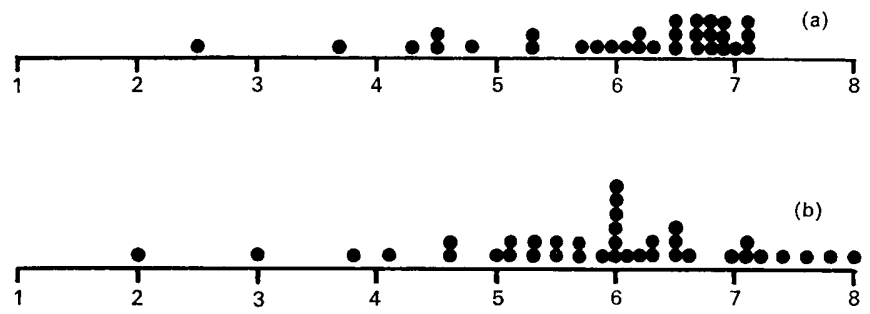

(c)

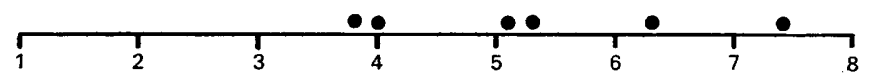

(d)

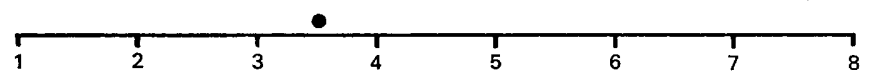

(e)

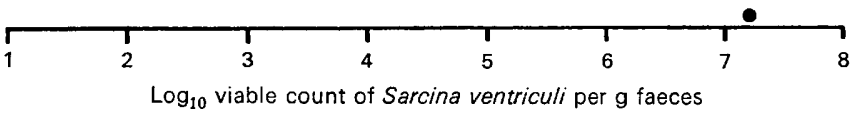

Fig. 2.-Numbers of sarcinae found in faeces of carriers. One dot represents the $\log _{10}$ viable count of sarcinae in the faeces of one person. The people lived in: (a) Kampala; (b) Vellore, South India; (c) London (these people ate strictly vegetarian diets); (d) Atlanta; (e) Khartoum. The sole carrier from Khartoum was an 8-yr-old girl. 
diets in various parts of the world. Sarcinae were isolated from 75 out of 106 people living on principally vegetarian or strict vegetarian diets, but from only 2 out of 123 people eating mixed diets containing animal and vegetable foods

TABLE II

Comparison of six faecal strains of Sarcina ventriculi with $S$. ventriculi strain HUI isolated from soil

\begin{tabular}{|c|c|c|c|c|c|}
\hline \multirow{2}{*}{ Test } & \multicolumn{4}{|c|}{ Result of test* with strains of $S$. ventriculi derived from } & \multirow{2}{*}{$\begin{array}{l}\text { Results with } \\
\text { strain HU1 } \\
\text { derived from } \\
\text { soil }\end{array}$} \\
\hline & $\begin{array}{l}\text { Uganda (1) } \\
\text { India }\end{array}$ & $\begin{array}{l}\text { Uganda (1) } \\
\text { India (1) }\end{array}$ & Uganda (1) & England (1) & \\
\hline $\begin{array}{l}\text { Aerobic growth } \\
\text { Growth without carbo- } \\
\text { hydrate } \\
\text { Fermentations at } 30 \text { days: } \\
\text { glucose } \\
\text { fructose } \\
\text { sucrose } \\
\text { maltose } \\
\text { lactose } \\
\text { galactose } \\
\text { raffinose } \\
\text { arabinose } \\
\text { dulcitol } \\
\text { glycerol } \\
\text { starch } \\
\text { salicin } \\
\text { mannitol } \\
\text { inulin } \\
\text { xylose } \\
\text { Production of: } \\
\text { ethanol from glucose } \\
\text { butyric acid from } \\
\text { glucose } \\
\text { extracellular cellulose } \\
\text { Nitrate reduction } \\
\text { Litmus milk } \\
\text { Gelatin liquefaction }\end{array}$ & $\begin{array}{l}+ \\
+ \\
+ \\
+ \\
+ \\
+ \\
+ \\
+ \\
- \\
- \\
- \\
= \\
- \\
- \\
- \\
+ \\
+ \\
+ \\
+ \\
+\end{array}$ & $\begin{array}{l}+ \\
+ \\
+ \\
+ \\
+ \\
+ \\
+ \\
+ \\
- \\
+ \\
+ \\
+ \\
- \\
- \\
+ \\
+ \\
+ \\
+ \\
+\end{array}$ & $\begin{array}{c}+ \\
+ \\
+ \\
+ \\
+ \\
+ \\
+ \\
- \\
- \\
- \\
- \\
(+) \\
+ \\
+ \\
- \\
+ \\
+ \\
- \\
+ \\
+ \\
(\mathrm{AC}) \\
-\end{array}$ & $\begin{array}{l}+ \\
+ \\
+ \\
+ \\
+ \\
+ \\
+ \\
- \\
- \\
- \\
- \\
(+) \\
(+) \\
(+) \\
(+) \\
+ \\
+ \\
+ \\
+ \\
(\text { AC) } \\
-\end{array}$ & $\begin{array}{l}+ \\
+ \\
+ \\
+ \\
+ \\
+ \\
+ \\
- \\
= \\
= \\
= \\
(+) \\
- \\
+ \\
+ \\
+ \\
+ \\
A\end{array}$ \\
\hline
\end{tabular}

$*+=$ Positive; $-=$ negative; $(+)=$ positive after 7 days; $\mathrm{AC}=$ acid clot; $(\mathrm{AC})=$ acid clot after 7 days.

(table I). In the carriers, the counts of sarcinae ranged from $10^{2}$ to $10^{8}$ per $\mathrm{g}$ faeces (fig. 2). Counts of $10^{6}$ and more were frequently found and this indicates that sarcinae were often as numerous as coliform organisms, streptococci and lactobacilli in faeces.

\section{Identification of sarcinae}

Sarcinae are now defined as obligately anaerobic, Gram-positive cocci forming cubical packets of eight (Kocur and Martinec, 1965; Canale-Parola, Mandel and Kupfer, 1967). Only two species capable of utilising sugars are recorded, Sarcina maxima and S. ventriculi (Breed and Smit, 1957). The main differences between them are that $S$. maxima has no extracellular cellulose and 
produces butyric acid from glucose, whilst $S$. ventriculi has extracellular cellulose and produces ethanol and not butyric acid from glucose.

Six strains of sarcinae, three from Ugandan, two from Indian and one from English faeces, were compared with a known strain of $S$. ventriculi. No type culture of $S$. maxima was available. All the strains were obligate anaerobes, formed cellulose and required a carbohydrate for growth; all produced ethanol but not butyric acid from glucose (table II). All strains produced acid and gas from glucose, fructose, sucrose, maltose, lactose, galactose and raffinose; none could utilise arabinose, dulcitol, glycerol or starch; salicin, mannitol, inulin and xylose were utilised by some strains, but growth was usually late. All strains, including the known culture of $S$. ventriculi, reduced nitrate to nitrite, which was then further reduced.

Although some strain-to-strain variations in biochemical reactions were found, the results show that the sarcinae isolated from human faeces were S. ventriculi.

\section{Discussion}

The results of the present study indicate that Sarcina ventriculi occurs frequently in the faeces of healthy human adults living in the tropics, but only rarely in faeces of people in temperate countries. However, none of the English immigrants in the Kampala series carried sarcinae whereas these organisms were carried by many of the Ugandans. The diet of the English immigrants was mixed and included animal meat whereas the principal item of the Ugandan diet was boiled bananas; furthermore, in London, sarcinae were found only in those English persons eating strictly vegetarian diets. This suggests, therefore, that diet and not environment is a major factor controlling the distribution of $S$. ventriculi in man.

S. ventriculi is widespread in the soil (Smit, 1933) and it seems inevitable that it is ingested as a contaminant on food. Since it occurs in faeces in numbers equal to those reported for coliforms, it seems likely that it multiplies, presumably in the large intestine, as the stomach and small intestine are rarely colonised by bacteria (Drasar et al., 1969). It is not known whether vegetarian foods stimulate the growth or whether animal foods inhibit the growth of the sarcinae. However, it seems likely that the addition of animal foods to the diet leads to an increase in the numbers and possibly a change in the types of the non-sporing anaerobes such as Bacteroides species and bifidobacteria (Aries et al., 1969). It is possible that some metabolites of these anaerobes, particularly organic acids, could inhibit the sarcinae. The short-chain fatty acids are known to inhibit $S$. ventriculi (Smit).

It is interesting that the known culture of $S$. ventriculi and the six strains isolated from faeces all reduced nitrate to nitrite which was then further reduced. Previous workers have not reported this reduction of nitrate, perhaps because, having shown that nitrite was absent, they omitted to test for residual nitrate.

Although S. ventriculi was often observed during the last century in the stomach contents of patients with gastric disorders, similar cases have been 
reported only rarely since. It is therefore interesting that Professor E. A. Dawes (personal communication), during the period 1959-60, found $S$. ventriculi in the stomach contents of patients in Glasgow with symptoms similar to those of the patient reported by Goodsir (1842).

It is suggested that $S$. ventriculi should now be considered to be part of the intestinal bacterial flora of man, but its significance in the intestine is not known.

\section{SUMMARY}

Anaerobic sarcinae were quantitatively isolated from suspensions of faeces heated at $70^{\circ} \mathrm{C}$ for $10 \mathrm{~min}$. by plating on meat infusion agar containing lactose, neutral red and egg-yolk and incubating anaerobically at $37^{\circ} \mathrm{C}$. Sarcina ventriculi was found in numbers up to $10^{8}$ per $\mathrm{g}$ in faeces from 75 out of 106 healthy human adults living on vegetarian diets, but the organism occurred in the faeces of only 2 out of 123 people living on diets containing animal products. The identification and distribution of the organism are discussed and it is concluded that diet influences the colonisation of sarcinae in the human intestine.

I am indebted to Dr R. Blowers (at the time Professor of Bacteriology at Makerere University College, Kampala, Uganda), Professor S. J. Baker (Wellcome Research Unit, Christian Medical College Hospital, Vellore, India), Dr P. S. Brachman (National Center for Disease Control, Atlanta, Georgia), Dr J. G. Collee (University Medical School, Edinburgh) and Dr F. R. Ellis (Kingston and Long Grove Hospitals, Kingston-uponThames, Surrey) for collecting the faecal specimens. Professor E. A. Dawes (Department of Biochemistry, University of Hull) kindly gave me the culture of $S$. ventriculi and allowed me to use some of his unpublished results. I thank Miss R. Steward for her technical help. The work was supported by the British Empire Cancer Campaign.

\section{REFERENCES}

Aries, Vivienne, Crowther, J. S., Drasar, B. S., Hill, M. J., and Williams, R. E. O. 1969. Bacteria and the aetiology of cancer of the large bowel. Gut, 10, 334.

BeIJERINCK, M. W. 1905. An obligative anaerobic fermentation Sarcina. Proc. Sect. Sci. K. ned. Akad. Wet., 7, 580.

BeIJerincK, M. W. 1911. An experiment with Sarcina ventriculi. Proc. Sect. Sci. K. ned. Akad. Wet., 13, 1237.

BREed, R. S., AND SMIT, J. 1957. In Bergey's Manual of determinative bacteriology, 7th ed., edited by R. S. Breed, E. G. D. Murray and N. R. Smith, London, p. 467.

Canale-Parola, E. 1970. Biology of the sugar-fermenting sarcinae. Bact. Rev., 34, 82.

Canale-Parola, E., Borasky, E. R., AND Wolfe, R. S. 1961. Studies on Sarcina ventriculi. III. Localization of cellulose. J. Bact., 81, 311.

Canale-Parola, E., Mandel, M., and Kupfer, Dorothy G. 1967. The classification of sarcinae. Arch. Mikrobiol., 58, 30.

Canale-Parola, E., and Wolfe, R. S. 1960. Studies on Sarcina ventriculi. I. Stock culture method. J. Bact., 79, 857.

Cato, Elizabeth P., Cummins, C. S., Holdeman, Lillian V., Johnson, J. L., Moore, W. E. C., Smibert, R. M., AND SMith, L. DS. 1969. In Outline of clinical methods in anaerobic bacteriology, Blacksburg, Virginia, p. 36.

Cowan, S. T., AND SteEL, K. J. 1965. Manual for the identification of medical bacteria, Cambridge, p. 161.

Crecelius, H. G., ANd Rettger, L. F. 1943. The intestinal flora of the guinea-pig. J. Bact., 46, 1.

J. MED. MICROBIOL. - VOL. 4 (1971) 
Drasar, B. S., Shiner, M., AND McLeod, G. M. 1969. Studies on the intestinal flora. I. The bacterial flora of the gastro-intestinal tract in healthy and achlorhydric persons. Gastroenterology, 56, 71.

GoodsIR, J. 1842. History of a case in which a fluid periodically ejected from the stomach contained vegetable organisms of an undescribed form. With a chemical analysis of the fluid by George Wilson. Edinb. Med. Surg. J., 57, 430.

KNöLL, H. 1965. Zur Biologie der Gärungssarcinen. Mber. dt. Akad. Wiss. Berl., 7, 475.

KocUr, M., AND Martinec, T. 1965. Some remarks on the classification of micrococci. Int. Bull. Bact. Nomencl. Taxon., 15, 113.

Schaedler, R. W., Dubos, R., and Costello, R. 1965. The development of the bacterial flora in the gastrointestinal tract of mice. J. Exp. Med., 122, 59.

SMIT, J. 1933. The biology of the fermenting sarcinae. J. Path. Bact., 36, 455.

Stephenson, M. P., AND DAwES, E. A. 1970. The role of ferredoxin in formate metabolism of Sarcina ventriculi. J. Gen. Microbiol., 60, vi.

WILlIS, A. T., AND HoBBs, G. 1958. A medium for the identification of clostridia producing opalescence in egg-yolk emulsions. J. Path. Bact., 75, 299. 